\title{
Mineral and phytate contents of some prepared popular Ghanaian foods
}

\author{
George Amponsah Annor, Kwaku Tano Debrah and Allen Essen
}

\begin{abstract}
Prepared Ghanaian traditional foods, mostly consist of starchy staples such as yams (Dioscorea spp.), cassava (Manihot esculenta), millet (Pennisetum glaucum), maize (Zea mays) and rice (Oryza sativa) etc. These traditional foods are a main source of energy and macronutrients. Little or no information however exist on the mineral and phytate contents of prepared traditional Ghanaian foods. The mineral and phytate contents of twenty commonly eaten Ghanaian foods, prepared using popular recipes were analysed for their $\mathrm{Fe}, \mathrm{Cu}, \mathrm{Zn}, \mathrm{Mg}, \mathrm{Mn}, \mathrm{Ca}, \mathrm{Na}$ and $\mathrm{K}$ as well as phytate contents after foods were dried. Sodium was high in most of the foods, ranging from $557 \mathrm{mg} / 100 \mathrm{~g}$ for Akple with okro soup, to 193.7 for Kooko and bread. Boiled cowpeas with fried plantain was found to contain the highest amount of potassium (409.0 mg/100 g) followed by konkonte with groundnut soup (384.7 mg/100 g). Kooko with bread recorded the lowest potassium content of $131.72 \mathrm{mg} / 100 \mathrm{~g}$. Konkonte with palm-nut soup and also with groundnut soup were among the foods found to contain high amounts of iron $(14.1 \mathrm{mg} / 100 \mathrm{~g}$ and $13.2 \mathrm{mg} / 100 \mathrm{~g}$ respectively). All the foods were very good sources of minerals and will significantly contribute to the mineral intakes of consumers; however, their sodium contents were of concern.
\end{abstract}

Keywords: Mineral, Ghanaian, Dishes, Phytate, Popular, Iron, Zinc, Calcium

\section{Background}

Ghana is known throughout West Africa for the variety and quality of its traditional cuisine. Across the country, different ethnic groups or tribes prepare foods differently with varied ingredients. These differences largely reflect the types of crops produced in the various regions of the country (Salm and Falola 2002). Ghanaian traditional foods consist mainly of starchy staples such as yams, cassava, millet, maize and rice etc. These staples are usually served with spicy soups or stews and portions of meat or fish. Common spices used in these Ghanaian dishes are ginger, garlic, chillies and nutmeg etc. Wild mushrooms, garden eggs (similar to eggplant) are examples of vegetables used. Some examples of common traditional Ghanaian foods are waakye (cooked rice and cowpeas), fufu (cooked and pounded cassava and plantain or cooked and pounded yam and plantain, or cooked and pounded cocoyam), banku (cooked fermented maize dough and

\footnotetext{
*Correspondence: georgeannor@gmail.com; gannor@ug.edu.gh Department of Nutrition and Food Science, University of Ghana, P.O. Box LG 134, Legon-Accra, Ghana
}

cassava dough), kenkey (cooked fermented maize dough wrapped in dried corn shooks or banana leaves), kokonte (cooked paste from fermented cassava flour) and gari (roasted cassava grits). Phytic acid is found in most cereal grains, legumes, nuts, oilseeds, tubers, pollen, spores, and organic soils. It acts as the primary phosphorus reserve accounting for up to $85 \%$ of the total phosphorus in cereals and legumes (Tsao et al. 1997). Since phytates cannot be absorbed, and humans have a limited capacity for hydrolysing the phytate molecule, a negative effect of phytic acid on mineral bioavailability can be expected (Lönnerdal et al. 1989). Minerals represent about 0.2$0.3 \%$ of the total intake of all nutrients in our diets and are necessary for the maintenance of normal cellular metabolism and tissue function (Sikorski 2006). Some attempts have been made to determine the mineral contents of some Ghanaian foods. A look through literature reveals little information on the mineral contents of prepared Ghanaian foods. The few studies available focused on ingredients rather than prepared foods. This study therefore aims at investigating the mineral of some prepared popular Ghanaian foods. 


\section{Results and discussion}

The minerals contents of the 20 popular Ghanaian foods, expressed on a dry weight basis in mg per $100 \mathrm{~g}$ edible portion are presented in Table 1 . The phytate content, phytate:zinc, phytate:iron, calcium:phytate and (calcium $\times$ phytate):zinc molar ratios for the food samples are also presented in Table 2 .

\section{Iron}

The iron content of foods analysed ranged from 3.6 to $15.5 \mathrm{mg} / 100 \mathrm{~g}$, with the highest being recorded for Hausa kooko with bread and akara, and the lowest in yam with garden-egg stew. Konkonte with palm nut soup and also with groundnut soup were among the foods found to contain high amount of iron at $14.1 \mathrm{mg} / 100 \mathrm{~g}$ and $13.5 \mathrm{mg} / 100 \mathrm{~g}$ respectively. Plantain with garden-egg stew $(4.1 \mathrm{mg} / 100 \mathrm{~g})$, kooko with bread $(4.8 \mathrm{mg} / 100 \mathrm{~g})$ and plain rice and stew $(4.3 \mathrm{mg} / 100 \mathrm{~g})$ contained quite low amounts of iron compared to the rest of the dishes. The high iron contents for some of the dishes may be due to the relatively high amounts of animal proteins (meat and fish) in these dishes. For example: konkonte with palm-nut soup contained $90 \mathrm{~g}$ of tuna and $47 \mathrm{~g}$ of meat and had an iron content of $14.1 \mathrm{mg} / 100 \mathrm{~g}$. There is evidence that phytic acid has a very marked inhibitory effect on the absorption of non-haem iron in man (Sandberg and Svanberg 1991), therefore, the high level of phytic acid $(20 \mathrm{mg} / 100 \mathrm{~g})$ detected in hausa kooko with bread and akara as well as kenkey with fried fish and pepper suggest that phytic acid may have an effect on the absorption of iron from these foods. The foods analysed had varied but high iron contents and consequently phytate:iron molar ratios were below 1.0 (Table 2). According to Hurell (2003), phytate begins to lose its inhibitory effect on iron absorption when phytate:iron molar ratios is less than 1.0. This study suggests that the absorption of intrinsic non-haem iron from these foods may not be significantly inhibited by phytate. Furthermore, the animal proteins (fish and meat) present in some of these dishes can counteract the inhibitory effect of phytic acid on iron absorption from the diet (Reddy et al. 1996).

\section{Copper}

Waakye with stew $(1550 \mu \mathrm{g} / 100 \mathrm{~g})$ had the highest amount of copper followed by $f u f u$ with groundnut soup and omo tuo with groundnut soup, both recording about $500 \mu \mathrm{g} / 100 \mathrm{~g}$ of copper. The lowest amount of copper was observed in plantain with garden-egg stew $(10 \mathrm{mg} / 100 \mathrm{~g})$. Hausa kooko with bread and akara, yam and kontomire stew and yam with garden-egg stew were equally found to be poor sources of copper (20,
60 and $70 \mu \mathrm{g} / 100 \mathrm{~g}$ respectively). In general, the copper content of the foods analysed in this study was quite low with copper was not detected in nine out of the twenty foods.

\section{Zinc}

Omo tuo with groundnut soup had a zinc content of $4.7 \mathrm{mg} / 100 \mathrm{~g}$, followed by $f u f u$ with groundnut soup $(4.2 \mathrm{mg} / 100 \mathrm{~g})$ and tuo zaafi $(4.0 \mathrm{mg} / 100 \mathrm{~g})$. The lowest level of zinc was seen in kooko with bread $(1.1 \mathrm{mg} / 100 \mathrm{~g})$ and plantain with garden egg stew $(1.7 \mathrm{mg} / 100 \mathrm{~g})$ as shown in Table 1. Because phytate is a major inhibitor of zinc absorption, the phytate:zinc molar ratio is used to estimate the likely absorption of zinc from a mixed diet (Shils et al. 2006). The phytate:zinc molar ratio of all the dishes analysed in this study were low (Table 2) and hence, a sign of good bioavailability. About $4.7 \mathrm{mg} / 100 \mathrm{~g}$ of zinc was recorded for omo tuo with groundnut soup.

\section{Calcium}

The calcium content of the dishes ranged from a high of $158.0 \mathrm{mg} / 100 \mathrm{~g}$ in konkonte with groundnut soup to a low of $4.9 \mathrm{mg} / 100 \mathrm{~g}$ in kooko with bread. Konkonte with palm nut soup (146.7 mg/100 g), plantain and kontomire stew $(116.1 \mathrm{mg} / 100 \mathrm{~g})$, yam with kontomire stew (103.6 mg/100 g) and kenkey with fried fish and pepper sauce $(100.0 \mathrm{mg} / 100 \mathrm{~g})$ had high calcium contents. Even though calcium is the most abundant mineral in the body, it is present in significant amount in very limited number of foods (Dunne 1990). Wise (1983) suggested that the solubility of phytates and the proportion of zinc bound in a mineral complex in the intestines depend on the levels of calcium. In his model, phytate precipitation is not complete until dietary calcium:phytate molar ratios attain a value of approximately $6: 1$. Based on this observation, the high calcium:phytate molar ratios observed in these foods may lead to a reduction in the level of bioavailable zinc when consumed. The calcium:phytate molar ratios of all the dishes, except konkonte with palm nut soup, were greater than $6: 1$ and this, according to Wise (1983), is regarded as unfavourable for calcium absorption from these foods. Even though, the low calcium content of some of the foods is undesirable, it is of an advantage because, high calcium content may also jeopardize bioavailability of iron (Hallberg and Hulthein 2000) and zinc (Wise 1983). According to Ellis et al. (1987) and Davies and Warrington (1986), if the (calcium $\times$ phytate): zinc values are $>0.50 \mathrm{~mol} / \mathrm{kg}$ there will be interference with zinc availability which will lead to increased risk of deficiency. High calcium levels in foods can promote the phytate-induced decrease in zinc bioavailability when the calcium $\times$ phytate:zinc mill molar ratio exceeds 0.5 (Gibson 1994). Therefore, as values $>0.5$ 
Table 1 Mineral (Fe, Cu, Zn, Ca, Mg, K, Mn and $\mathrm{Na}$ ) contents of popular Ghanaian foods

\begin{tabular}{|c|c|c|c|}
\hline Foods & Moisture (g/100 g) & Iron (mg) & Copper $(\mu \mathrm{g})$ \\
\hline Yam with kontomire stew & $93.9 \pm 0.2$ & $6.6 \pm 0.1$ & $60 \pm 10$ \\
\hline Yam with garden egg stew & $92.1 \pm 0.2$ & $3.6 \pm 0.1$ & $70 \pm 20$ \\
\hline Plantain with kontomire stew & $93.3 \pm 0.1$ & $7.1 \pm 0.1$ & ND \\
\hline Plantain with garden egg stew & $91.5 \pm 0.2$ & $4.1 \pm 0.1$ & $10 \pm 10$ \\
\hline Fufu with light soup & $86.3 \pm 0.1$ & $8.1 \pm 0.1$ & $360 \pm 20$ \\
\hline Fufu with palm-nut soup & $93.4 \pm 0.1$ & $6.3 \pm 0.2$ & $440 \pm 20$ \\
\hline Fufu with groundnut soup & $87.1 \pm 0.2$ & $10.5 \pm 0.2$ & $500 \pm 10$ \\
\hline Konkonte with palm-nut soup & $93.5 \pm 0.2$ & $14.1 \pm 0.5$ & ND \\
\hline Konkonte with groundnut soup & $92.7 \pm 0.3$ & $13.2 \pm 0.4$ & ND \\
\hline Akple with okro soup & $91.0 \pm 0.1$ & $5.3 \pm 0.6$ & ND \\
\hline Kooko with bread & $91.4 \pm 0.2$ & $4.8 \pm 0.2$ & ND \\
\hline Kenkey with fried fish and pepper & $94.3 \pm 0.2$ & $13.0 \pm 0.3$ & ND \\
\hline Jollof rice & $95.1 \pm 0.1$ & $4.8 \pm 0.0$ & ND \\
\hline Plain rice and stew & $95.0 \pm 0.1$ & $4.3 \pm 0.0$ & ND \\
\hline Omo tuo with palm-nut soup & $91.4 \pm 0.2$ & $12.5 \pm 0.3$ & ND \\
\hline Omo tuo with groundnut soup & $86.9 \pm 0.1$ & $11.1 \pm 0.1$ & $500 \pm 10$ \\
\hline Waakye with stew & $95.1 \pm 1.0$ & $5.3 \pm 0.1$ & $1550 \pm 310$ \\
\hline Hausa Kooko with bread and akara & $91.1 \pm 0.1$ & $15.5 \pm 0.3$ & $20 \pm 2$ \\
\hline Tuo zaafi & $90.9 \pm 0.2$ & $7.7 \pm 0.0$ & ND \\
\hline Beans with fried plantain & $94.5 \pm 0.2$ & $8.0 \pm 0.2$ & $90 \pm 9$ \\
\hline Foods & Zinc (mg) & Calcium (mg) & $\begin{array}{l}\text { Magnesium } \\
(\mathrm{mg})\end{array}$ \\
\hline Yam with kontomire stew & $2.5 \pm 0.1$ & $103.6 \pm 0.8$ & $43.3 \pm 0.8$ \\
\hline Yam with garden egg stew & $2.2 \pm 0.1$ & $13.5 \pm 0.1$ & $41.2 \pm 0.7$ \\
\hline Plantain with kontomire stew & $2.01 \pm 0.1$ & $116.1 \pm 0.9$ & $46.4 \pm 0.3$ \\
\hline Plantain with garden egg stew & $1.7 \pm 0.1$ & $26.0 \pm 0.2$ & $44.2 \pm 0.2$ \\
\hline Fufu with light soup & $3.8 \pm 0.1$ & $12.2 \pm 0.2$ & $42.7 \pm 0.5$ \\
\hline Fufu with palm-nut soup & $2.2 \pm 0.1$ & $27.5 \pm 0.3$ & $45.3 \pm 0.4$ \\
\hline Fufu with groundnut soup & $4.2 \pm 0.1$ & $10.6 \pm 0.2$ & $44.5 \pm 0.3$ \\
\hline Konkonte with palm-nut soup & $3.3 \pm 0.0$ & $146.7 \pm 0.5$ & $44.6 \pm 0.2$ \\
\hline Konkonte with groundnut soup & $3.1 \pm 0.1$ & $158.2 \pm 05$ & $47.1 \pm 0.1$ \\
\hline Akple with okro soup & $3.0 \pm 0.1$ & $14.5 \pm 0.1$ & $45.7 \pm 0.1$ \\
\hline Kooko with bread & $1.1 \pm 0.0$ & $4.9 \pm 0.0$ & $35.8 \pm 0.3$ \\
\hline Kenkey with fried fish and pepper & $2.8 \pm 0.1$ & $100.0 \pm 1.0$ & $45.3 \pm 0.4$ \\
\hline Jollof rice & $3.5 \pm 0.0$ & $9.6 \pm 0.1$ & $39.0 \pm 0.5$ \\
\hline Plain rice and stew & $2.8 \pm 0.1$ & $59.8 \pm 0.3$ & $41.8 \pm 0.6$ \\
\hline Omo tuo with palm-nut soup & $2.7 \pm 0.1$ & $48.7 \pm 0.3$ & $45.5 \pm 0.5$ \\
\hline Omo tuo with groundnut soup & $4.7 \pm 0.1$ & $9.8 \pm 0.2$ & $38.5 \pm 0.3$ \\
\hline Waakye with stew & $2.9 \pm 0.1$ & $24.7 \pm 0.2$ & $46.7 \pm 0.2$ \\
\hline Hausa kooko with bread and akara & $2.3 \pm 0.1$ & $9.9 \pm 0.1$ & $42.2 \pm 0.2$ \\
\hline Tuo zaafi & $4.0 \pm 0.1$ & $28.7 \pm 0.2$ & $46.8 \pm 0.6$ \\
\hline Beans with fried plantain & $2.9 \pm 0.0$ & $21.3 \pm 0.2$ & $46.5 \pm 0.1$ \\
\hline Foods & Potassium (mg) & Manganese (mg) & Sodium (mg) \\
\hline Yam with kontomire stew & $374.0 \pm 1.8$ & $0.7 \pm 0.1$ & $443.3 \pm 1.3$ \\
\hline Yam with garden egg stew & $367.7 \pm 1.5$ & $0.4 \pm 0.0$ & $423.0 \pm 1.0$ \\
\hline Plantain with kontomire stew & $371.0 \pm 1.8$ & $0.8 \pm 0.1$ & $409.2 \pm 1.5$ \\
\hline Plantain with garden egg stew & $364.7 \pm 1.5$ & $0.5 \pm 0.0$ & $388.8 \pm 1.3$ \\
\hline Fufu with light soup & $379.8 \pm 2.6$ & $0.6 \pm 0.1$ & $360.8 \pm 1.8$ \\
\hline
\end{tabular}


Table 1 continued

\begin{tabular}{llll}
\hline Foods & Potassium $(\mathbf{m g})$ & Manganese (mg) & Sodium (mg) \\
\hline Fufu with palm-nut soup & $351.8 \pm 2.1$ & $0.6 \pm 0.0$ & $303.8 \pm 1.8$ \\
Fufu with groundnut soup & $353.5 \pm 1.8$ & $0.7 \pm 0.1$ & $367.3 \pm 1.8$ \\
Konkonte with palm-nut soup & $340.3 \pm 1.5$ & $0.8 \pm 0.1$ & $353.3 \pm 2.1$ \\
Konkonte with groundnut soup & $384.7 \pm 1.5$ & $0.9 \pm 0.1$ & $409.7 \pm 1.5$ \\
Akple with okro soup & $330.0 \pm 1.0$ & $0.7 \pm 0.1$ & $556.7 \pm 1.5$ \\
Kooko with bread & $131.7 \pm 1.5$ & $0.5 \pm 0.0$ & $193.7 \pm 1.5$ \\
Kenkey with fried fish andpepper & $266.7 \pm 1.5$ & $0.7 \pm 0.6$ & $498.3 \pm 1.5$ \\
Jollof rice & $235.7 \pm 1.5$ & $0.8 \pm 0.0$ & $507.0 \pm 1.0$ \\
Plain rice and stew & $185.7 \pm 1.5$ & $0.8 \pm 0.1$ & $1.0 \pm 0.0$ \\
Omo tuo with palm-nut soup & $230.0 \pm 2.0$ & $0.8 \pm 0.5$ & $542.0 \pm 1.0$ \\
Omo tuo with groundnut soup & $205.0 \pm 0.2$ & $1.1 \pm 0.1$ & $556.0 \pm 1.0$ \\
Waakye with stew & $292.3 \pm 2.1$ & $1.2 \pm 0.1$ & $511.2 \pm 1.5$ \\
Hausa kooko with bread and akara & $166.7 \pm 1.5$ & $1.3 \pm 0.2$ & $523.0 \pm 1.0$ \\
Tuo zaafi & $376.0 \pm 2.0$ & $1.1 \pm 0.2$ & $236.0 \pm 1.0$ \\
Beans with fried plantain & $409.0 \pm 1.0$ & & $492.0 \pm 1.0$ \\
\hline
\end{tabular}

Means \pm standard deviations

ND not detected

Table 2 Concentration of phytate and phytate:zinc, phytate:iron, calcium:phytate and [Ca] [phytate]:[Zn] molar ratios of the popular Ghanaian foods

\begin{tabular}{|c|c|c|c|c|c|}
\hline Dishes & Phytate $(\mathrm{mg} / 100 \mathrm{~g})$ & Phy:Zn & Phy:Fe & Ca:Phy & {$[\mathrm{Ca} \times \mathrm{Phy}]:[\mathrm{Zn}]$} \\
\hline Yam with kontomire stew & 15.72 & 0.6 & 0.2 & 107.9 & 0.02 \\
\hline Yam with garden egg stew & 8.75 & 0.4 & 0.2 & 25.4 & 0.001 \\
\hline Plantain with kontomire stew & 7.15 & 0.4 & 0.1 & 267.2 & 0.01 \\
\hline Plantain with garden egg stew & 0.18 & 0.01 & 0.004 & 2377.8 & 0 \\
\hline Fufu with light soup & 9.11 & 0.2 & 0.1 & 22 & 0.001 \\
\hline Fufu with palm nut soup & 9.11 & 0.4 & 0.1 & 49.7 & 0.002 \\
\hline Fufu with groundnut soup & 8.93 & 0.2 & 0.1 & 19.5 & 0 \\
\hline Konkonte with palm nut soup & 0 & 0 & 0 & 0 & 0 \\
\hline Konkonte with groundnut and soup. & 1.79 & 0.1 & 0.01 & 1455.4 & 0.002 \\
\hline Akple with okro soup & 18.57 & 0.6 & 0.3 & 12.7 & 0.002 \\
\hline Kooko with bread & 5.36 & 0.5 & 0.1 & 15.1 & 0.001 \\
\hline Kenkey with fried fish and pepper & 20 & 0.7 & 0.1 & 82.3 & 0.02 \\
\hline Jollof rice & 6.07 & 0.2 & 0.1 & 26 & 0 \\
\hline Plain rice and stew & 10 & 0.4 & 0.2 & 98.5 & 0.01 \\
\hline Omo tuo with palm-nut soup & 15.71 & 0.6 & 0.1 & 51 & 0.01 \\
\hline Omo tuo with groundnut soup & 8.4 & 0.2 & 0.1 & 19.2 & 0 \\
\hline Waakye with stew & 17.5 & 0.6 & 0.3 & 23.2 & 0.003 \\
\hline Hausa kooko with bread and akara & 20 & 0.9 & 0.1 & 8.2 & 0.002 \\
\hline Tuo zaafi & 12.5 & 0.3 & 0.1 & 37.9 & 0.002 \\
\hline Beans with fried plantain & 12.14 & 0.4 & 0.1 & 28.8 & 0.002 \\
\hline
\end{tabular}

The Phy:Zn, Phy:Fe, Ca:Phy and [Ca $\times$ Phy]:[Zn] values were calculated using the method of Wyatt and Triana-Tejas (1994)

were observed in these dishes, it would appear that the possible contribution of calcium in the diet in exacerbating the low bioavailability of zinc due to phytate is probably minimal.

\section{Magnesium}

Magnesium was found to be high in konkonte with groundnut soup $(47.1 \mathrm{mg} / 100 \mathrm{~g})$ with the lowest occurring in kooko with bread $(35.8 \mathrm{mg} / 100 \mathrm{~g})$. High 
values were also recorded in foods such as tuo zaafi $(46.8 \mathrm{mg} / 100 \mathrm{~g})$, waakye with stew $(46.7 \mathrm{mg} / 100 \mathrm{~g})$ and also in plantain with kontomire $(46.4 \mathrm{mg} / 100 \mathrm{~g})$. Konkonte with groundnut soup appeared to contain the highest level of magnesium (47.1 mg/100 g). The high magnesium level observed in this particular dish could be due to the presence of groundnut which serves as the major ingredient in the preparation of the soup (Havel et al. 1989). The low levels of magnesium in some of the dishes (cereal based dishes) could also be attributed to the removal of the germ and outer layers of the cereal grains which accounts for more than $80 \%$ loss in magnesium (Havel et al. 1989).

\section{Potassium}

Cooked cowpeas (popularly called beans) with fried plantain was found to contain the highest amount of potassium $(409.0 \mathrm{mg} / 100 \mathrm{~g})$ followed by konkonte with groundnut soup $(384.7 \mathrm{mg} / 100 \mathrm{~g})$. Tuo zaafi $(376.8 \mathrm{mg} / 100 \mathrm{~g})$, yam with kontomire $(374.0 \mathrm{mg} / 100 \mathrm{~g})$, plantain with kontomire stew $(371.0 \mathrm{mg} / 100 \mathrm{~g})$ and fufu with light soup $(3798 \mathrm{mg} / 100 \mathrm{~g})$ all had an appreciable amount of potassium.

\section{Manganese}

Most of the dishes had low levels of manganese except for $1.3 \mathrm{mg} / 100 \mathrm{~g}$ in tuo zaafi, $1.2 \mathrm{mg} / 100 \mathrm{~g}$ in hausa kooko with bread and $1.1 \mathrm{mg} / 100 \mathrm{~g}$ in beans with fried plantain. A lower value of $0.4 \mathrm{mg} / 100 \mathrm{~g}$ was observed in yam with garden egg stew and $0.5 \mathrm{mg} / 100 \mathrm{~g}$ in plantain with kontomire stew. The main staple food which forms the carbohydrate portion of tuo zaafi is millet (or corn flour in some cases) and this could possibly could account for the high manganese content, as whole grains and cereal products have been found to be the richest sources of manganese (Havel et al. 1989). Dishes which had their manganese levels between 1.0 and $1.2 \mathrm{mg} / 100 \mathrm{~g}$ such as omo tuo with palm nut soup (1.0 $\mathrm{mg} / 100 \mathrm{~g})$, waakye with stew $(1.1 \mathrm{mg} / 100 \mathrm{~g})$ and hausa kooko with bread and akara $(1.2 \mathrm{mg} / 100 \mathrm{~g})$ also have cereals forming the main portion of these foods.

\section{Sodium}

Sodium was quite high in most of the dishes analysed. Values from $556.7 \mathrm{mg} / 100 \mathrm{~g}$ in akple with okro soup, $556.0 \mathrm{mg} / 100 \mathrm{~g}$ in omo tuo with palm nut soup and $507.0 \mathrm{mg} / 100 \mathrm{~g}$ in jollof rice were observed. The lowest amount of sodium, $193.7 \mathrm{mg} / 100 \mathrm{~g}$, was recorded in kooko with bread. Akple with okro soup, omo tuo with palm nut soup and jollof rice had the highest amount of sodium $(556.7 \mathrm{mg} / 100 \mathrm{~g}),(556.0 \mathrm{mg} / 100 \mathrm{~g})$ and $(507.0 \mathrm{mg} / 100 \mathrm{~g})$ respectively, which were also quite higher than the safe and adequate intake levels of
$500 \mathrm{mg} /$ day. The remaining dishes had lower amounts of sodium which can be described as desirable since sodium reduction in the diet is recommended as means of preventing hypertension and subsequent cardiovascular disease, stroke and renal failure (Sikorski 2006).

\section{Phytate}

The level of phytate in the foods were high, ranging from about $20.0 \mathrm{mg} / 100 \mathrm{~g}$ in kenkey with fried fish and pepper sauce as well as hausa kooko with bread and akara. Konkonte with palm nut soup had no phytates. This could probably be due to the fact that konkonte is prepared from fermented cassava. Fermentation is known to reduce the phytates in foods. All the dishes showed marked variability in their level of phytate. Maize and millet goes through the process of soaking in water, milling and fermentation, before they are finally used in the preparation/cooking of kenkey and hausa kooko respectively. This might have accounted for the observed low level of phytate in these foods.

\section{Conclusions}

This study has established that the popular prepared Ghanaian foods are very good sources of iron, copper, zinc, calcium, magnesium, potassium and manganese. Most of these foods are also likely to meet more than $100 \%$ of the daily requirements (RDA) of these minerals. The sodium contents in these diets was however of a concern considering the implications on the consumption of high sodium consumption on heart health.

\section{Materials and methods Preparation of meals}

The preparation methods used for the chosen recipes are those described by Manu (2006). Ingredients used for the preparation of the meals were purchased from three local markets; Agbogbloshie, Madina and Kaneshie markets in the Greater Accra region. The meals were prepared in two commercial kitchen facilities, both located at the University of Ghana. A summary of the ingredients and method of preparation of the various dishes is shown in Table 3.

\section{Sample collection and preparation}

Each of the meals were prepared separately in the different commercial kitchens. After the preparation of the meals, each meal was cooled to room temperature and the whole meal homogenized using a waring blender. The homogenized meals were dried in an air-oven at $50{ }^{\circ} \mathrm{C}$ overnight and ground into flour using a mortar and pestle. The dried meals were packed in moisture resistant polyethylene bags and kept at approximately $4{ }^{\circ} \mathrm{C}$ for further analysis. The meals from the different commercial 
Table 3 Description of standardized foods

\begin{tabular}{|c|c|c|}
\hline Foodstuff & Food & Description \\
\hline \multirow[t]{2}{*}{ (a) Yam (Dioscorea rotundata) } & Yam and nkontomire stew & $\begin{array}{l}\text { Boiled yam with stew prepared from boiled cocoyam leaves, } \\
\text { tomatoes, onion and palm oil with fried/smoked fish }\end{array}$ \\
\hline & Yam and garden egg stew & $\begin{array}{l}\text { Boiled yam with stew prepared from boiled and ground garden } \\
\text { eggs, tomatoes, onion, pepper and palm oil with fried and } \\
\text { smoked fish }\end{array}$ \\
\hline \multirow[t]{2}{*}{ (b) Plantain (Musa sapientum) } & Plantain and nkontomire stew & $\begin{array}{l}\text { Boiled plantain with stew prepared from cocoyam leaves, toma- } \\
\text { toes, onion and palm oil with fried/smoked fish }\end{array}$ \\
\hline & Plantain and garden egg stew & $\begin{array}{l}\text { Boiled plantain with stew prepared from boiled and ground } \\
\text { garden eggs, tomatoes, onion, pepper and palm oil with fried } \\
\text { and smoked fish }\end{array}$ \\
\hline \multirow[t]{4}{*}{ (c) Cassava (Manihot esculenta) } & Fufu with palm nut soup & $\begin{array}{l}\text { Boiled cassava and plantain was pounded to a smooth paste in } \\
\text { a wooden mortar. Soup contained tomatoes, onions, pepper, } \\
\text { garden eggs, salt, water and fish/meat }\end{array}$ \\
\hline & Fufu and peanut soup & $\begin{array}{l}\text { Boiled cassava and plantain was pounded to a smooth paste. } \\
\text { Soup was prepared from peanut paste, tomatoes, pepper, } \\
\text { garden eggs, salt, water and fish/meat }\end{array}$ \\
\hline & Konkonte and palm nut soup & $\begin{array}{l}\text { Fermented cassava flour cooked to a paste with water. Soup con- } \\
\text { tained tomatoes, pepper, onions, salt, water and fish/meat }\end{array}$ \\
\hline & Konkonte and peanut soup & $\begin{array}{l}\text { Fermented cassava flour cooked to a paste with water. The soup } \\
\text { was prepared from peanut paste, tomatoes, pepper, garden } \\
\text { eggs, salt, water and fish/meat }\end{array}$ \\
\hline \multirow[t]{3}{*}{ (d) Maize (Zea mays) } & Akple and okro soup & $\begin{array}{l}\text { Cooked non-fermented corn dough and cassava dough. Soup } \\
\text { contained okro, tomatoes, pepper, garden eggs, onions, salt and } \\
\text { smoked/grilled fish or meat }\end{array}$ \\
\hline & Kooko with bread (fermented corn meal porridge) & $\begin{array}{l}\text { Porridge prepared from fermented corn dough and served with } \\
\text { bread }\end{array}$ \\
\hline & Kenkey with fried fish and pepper. & $\begin{array}{l}\text { Fermented corn dough boiled and stirred into a smooth paste. } \\
\text { Paste was moulded into balls, wrapped in clean corn shooks and } \\
\text { steamed for } 2-3 \mathrm{~h} \text {. It was served with fried fish, sliced onions } \\
\text { and pepper sauce }\end{array}$ \\
\hline \multirow[t]{5}{*}{ (e) Rice (Oryza sativa) } & Jollof rice and stew & $\begin{array}{l}\text { Rice cooked with tomatoes, pepper, salt, onions, meat, lard, thyme, } \\
\text { water and meat }\end{array}$ \\
\hline & Plain rice and stew & $\begin{array}{l}\text { Boiled rice served with stew prepared from tomatoes, onions, } \\
\text { pepper, salt, cooking oil and fish/meat }\end{array}$ \\
\hline & Omo tuo with palm nut soup & $\begin{array}{l}\text { Cooked rice made into balls and served with palm nut soup (as } \\
\text { described above) }\end{array}$ \\
\hline & Omo tuo with groundnut soup & Cooked rice made into balls and served with groundnut soup \\
\hline & Waakye with stew & $\begin{array}{l}\text { Rice cooked together with beans and served with macaroni, gari } \\
\text { and stew prepared with tomatoes, onions, pepper, salt, cooking } \\
\text { oil and fish/meat }\end{array}$ \\
\hline \multirow[t]{2}{*}{ (f) Millet (Pennisetum typhoides) } & Hausa kooko with bread and akara & $\begin{array}{l}\text { Ground millet and about one-third pepper cooked with water to } \\
\text { form porridge and served with sugar, bread and akara }\end{array}$ \\
\hline & Tuo Zaafi & $\begin{array}{l}\text { Boiled and thickened porridge ball prepared from millet and } \\
\text { served with soup containing tomatoes, pepper, onions, okro, } \\
\text { kontomire leaves and fish/meat }\end{array}$ \\
\hline (g) Cowpea (Vigna ungiculata) & Beans and fried ripe plantain (red-red) & Cooked beans served with palm oil, gari and fried ripe plantain \\
\hline
\end{tabular}

kitchens were analysed separately and means of the different analysis found. The preparations were done twice in the separate kitchens.

\section{Methods \\ Moisture determination}

The moisture contents of the samples were determined using the air-oven method described by Osborne and
Voogt (1978). Moisture dishes were cleaned, dried in oven and labelled for identification. Dishes together with the lid were weighed after cooling in a desiccator to determine the exact weight. In the method, approximately $2 \mathrm{~g}$ of the sample was weighed into each moisture dish. Samples were then dried at $105^{\circ} \mathrm{C}$ overnight in the air oven leaving the covers slightly opened. Then content of the moisture dishes was then cooled in a desiccator 
and weighed using an electronic weighing balance (AFA 210 LC, Adam Equipment). The percentage moisture determined was then used to calculate the percentage total solids content of the samples.

\section{Wet digestion of sample}

The first step involved in the determination of the inorganic materials was through the procedure of wet ashing. The AOAC 1990 method was employed. The glass wares were acid-washed overnight in $2 \mathrm{M} \mathrm{HCL}$ rinsed with distilled water and the oven dried $1 \mathrm{~g}$ of sample was weighed (Weighing balance, AFA 210 LC, Adam Equipment) into a dry acid-washed $250 \mathrm{ml}$ beaker. Twenty-five $\mathrm{ml}(25 \mathrm{ml})$ of concentrated nitric acid was added and the beaker covered with a watch glass. The sample was digested with great care on hot plot (Hot plate, Sand Juniper and Co. Harlow, Essex, England) in a fume chamber until the solution was pale yellow. The solution was cooled and $1 \mathrm{ml}$ Perchloric acid (70\% $\left.\mathrm{HCLO}_{4}\right)$ added. The digestion was continued until the solution was colourless or nearly so (the evacuation of dense fumes indicates the removal of nitric acid). When the digestion was completed, the solution was cooled slightly and $30 \mathrm{ml}$ of deionised water added. The mixture was brought to boiling for $10 \mathrm{~min}$ and filtered while hot, into a $100 \mathrm{ml}$ volumetric flask using a Whatman No. 4 filter paper. The solution was then made to the mark with deionised water. Flasks were stoppered and stored in a cold room at $10{ }^{\circ} \mathrm{C}$ awaiting mineral analysis.

\section{Determination of $\mathrm{Fe}, \mathrm{Cu}, \mathrm{Zn}, \mathrm{Mg}, \mathrm{Mn}$ and $\mathrm{Ca}$}

One $\mathrm{ml}$ of the digest was used to determine the $\mathrm{Fe}, \mathrm{Cu}$, $\mathrm{Zn}, \mathrm{Mg}, \mathrm{Mn}$ and $\mathrm{Ca}$ contents of the samples using the Perking Elmer Precisely A Analyst 400 Atomic Absorbance Spectrophotometer with an acetylene flame. The AAS was fitted with $\mathrm{Zn}$ and Fe EDL lamps and $\mathrm{Mg}, \mathrm{Mn}$, $\mathrm{Cu}$ and $\mathrm{Ca}$ CHCL lamps set at wavelengths of 213.86, $248.33,285.21,279.5,324.75,422.67 \lambda$ respectively.

\section{Determination of $\mathrm{Na}$ and $\mathrm{K}$}

Two (2) $\mathrm{ml}$ of the digest was used in the determination of sodium and potassium using the flame photometric method. The photometer (Jenway, United Kingdom) model PF P7 with methane gas was used for this analysis.

\section{Phytate determination}

Phytate determination in the food samples followed the method of Wheeler and Ferrel (1971). Ten (10) g of a finely ground sample (40 screen) estimated to contain 5-50 g P-phytate was weighed into a $125 \mathrm{ml}$ Erlenmeyer flask. Phytate was extracted with $50 \mathrm{ml} 3 \%$ solution of trichloroacetic acid for $30 \mathrm{~min}$ with constant agitation. The resulting suspension was centrifuged (Denley BS400
Centrifuge, Payne, England) at 160 revolutions per minute for $30 \mathrm{~min}$ and a $10 \mathrm{ml}$ aliquot of the supernatant liquid was transferred into a conical centrifuge tube. $4 \mathrm{ml}$ of $\mathrm{FeCl}_{3}$ solution prepared to contain $2 \mathrm{mg} \mathrm{Fe}{ }^{3+}$ was added, blowing through the pipette rapidly. The centrifuge tube containing the sample was heated for $45 \mathrm{~min}$ in a water bath (Nickel Electronics Ltd, England) at $90-100{ }^{\circ} \mathrm{C}$. (When the supernatant was not clear after $30 \mathrm{~min}$, 2 drops of the solution of sodium sulphate at $3 \%$ in trichoroacetic acid (TCA) was added and heated for 10 more minutes). The solution was centrifuged for $15 \mathrm{~min}$ at 160 revolutions per minutes and the supernatant liquid was carefully poured off. The remaining precipitate was washed twice with $20 \mathrm{ml}$ TCA at $3 \%$ solution, dispersing it well and heating for $10 \mathrm{~min}$ in boiling water and centrifuging for $15 \mathrm{~min}$ at 160 revolutions per minute. The wash was finally repeated once more with distilled water. The resulting precipitate was dispersed in a little distilled water followed by the addition $3 \mathrm{ml}$ of $1.5 \mathrm{~N} \mathrm{NaOH}$ solution and stirring. The volume of the solution was brought to approximately $30 \mathrm{ml}$ with distilled water and heated in boiling water for $30 \mathrm{~min}$. The solution was filtered whilst hot with a Whatman No. 4 filter paper. The precipitate was washed with $60 \mathrm{ml}$ of hot distilled water and the filtrate was discarded. The precipitate left in the paper was dissolved with $40 \mathrm{ml}$ of $3.2 \mathrm{~N}$ solution of $\mathrm{HNO}_{3}$ transferring it to a $100 \mathrm{ml}$ volumetric flask. The paper was washed several times with distilled water, collecting it in the flask. The sample was then cooled to room temperature and calibrated with distilled water. Five (5) $\mathrm{ml}$ of this solution was transferred into a $100 \mathrm{ml}$ volumetric flask and diluted to approximately $70 \mathrm{ml}$ with distilled water. $20 \mathrm{ml}$ of $1.5 \mathrm{~N} \mathrm{KSCN}$ was then added and the solution was made up to the $100 \mathrm{ml}$ mark with distilled water. Absorbance of the solution was read (approximately within $1 \mathrm{~min}$ ) in a spectrophotometer (Spectrophotometer UV-120-02, Shimadzu Cooperation, Japan) at $480 \mathrm{~nm}$. All readings were corrected by the reading of a blank carried out alongside each set of samples in order to eliminate the effect of any colour produced by the reagents. A standard curve colorimetric reading versus concentration of $\mathrm{Fe}^{3+}$ using portions of standard iron solutions $(2,4,6,8,10$ and $12 \mathrm{ml})$ subjected to reaction with potassium thiocynate was drawn, from which the concentrations of iron was obtained. The phytate content was then calculated from the iron concentration by assuming a constant Fe:P molecular ratio of $4: 6$ in the precipitate.

\section{Laboratory precautions}

To minimize the risk of adventitious contamination, all glassware used for the analytical methods for the analytical methods was acid-washed, and sterile disposable 
powder-free plastic gloves were worn when handling the foodstuffs during the sampling and analysis stages.

\section{Authors' contributions}

GAA, KTD, AE were involved in the planning and execution of study and writing of manuscript. All authors read and approved the final manuscript.

\section{Acknowledgements}

The authors have duly acknowledged all who contributed to the study.

\section{Competing interests}

The authors declare that they have no competing interests.

Received: 20 December 2015 Accepted: 20 April 2016

Published online: 10 May 2016

\section{References}

AOAC (1990) Official methods of analysis of the association of official analytical chemists, 15th edn. Arlington, Virginia

Davies NT, Warrington S (1986) The phytic acid, mineral, trace element, protein and moisture content of UK Asian immigrant foods. Hum Nutr Appl Nutr 40A:49-59

Dunne JL (1990) Nutrition almanac, 3rd edn. McGraw Hill Publishing Company New York, pp 32-35

Ellis R, Kelsey JL, Reynolds RD, Morris ER, Moser PB, Frazier CW (1987) Phytate:zinc and phytate $\times$ calcium:zinc millimolar ratios in self-selected diets of Americans, Asian Indians and Nepalese. J Am Diet Assoc 87(8):1043-1047

Gibson RS (1994) Zinc nutrition in developing countries. Nutr Res Rev 7:151-173

Hallberg L, Hulthein L (2000) Prediction of dietary iron absorption: an algorithm for calculating absorption and bioavailability of dietary iron. Am J Clin Nutr 71:1147-1160
Havel RJ, Galloway DH, Gussow JD, Mertz W, Nesheim MC (1989) Recommended dietary allowances, 1st edn. The National Academy of Sciences, USA, pp 189-190, 255, 230, 250

Hurell RF (2003) Influence of vegetable protein sources on trace element and mineral bioavailability. J Nutr 133:2973S-2977S

Lönnerdal B, Sandberg AS, Sandstrom B, Kunz C (1989) Inhibitor effects of phytic acid and other inositol phosphates on zinc and calcium absorption in suckling rats. J Nutr 119:211-214

Manu S (2006) Ghanaian cook book, 1st edn. Adaex Educational Publications Ltd, Accra-Ghana, pp 7-179

Osborne DR, Voogt V (1978) The analysis of nutrients in foods. Academic Press Inc, London

Reddy NR, Pierson MD, Sathe SK, Salunkhe DK (1996) Phytates in cereals and legumes. CRC Press, Boca Raton, p 57

Salm SJ, Falola T (2002) Culture and customs of Ghana, 1st edn. Greenwood and Publishing Group, Westport, pp 105-109

Sandberg AS, Svanberg U (1991) Phytate hydrolysis by phytase in cereals: effects on in vitro estimation of iron availability. J Food Sci 56:1330-1333

Shils ME, Shike M, Ross AC, Caballlero B, Cousins RJ (2006) Modern nutrition in health and diseases, 10th edn. Lippincott Williams and Wilkins, Philadelphia, p 273

Sikorski ZE (2006) Chemical and functional properties of food components, 3rd edn. CRC Press, Florida, pp 61, 66, 67, 73, 74

Tsao GT, Zheng Y, Lu J, Gong CS (1997) Adsorption of heavy metal ions by immobilized phytic acid. Appl Biochem Biotech 63:731-741

Wheeler EL, Ferrel RE (1971) A method for phytic acid determination in wheat and wheat fractions. Cereal Chem 48:312-320

Wise A (1983) Dietary factors determining the biological activities of phytate. Nutr Abstr Rev 53:791-806

Wyatt CJ, Triana-Tejas A (1994) Soluble and insoluble Fe, Zn, Ca and phytates in foods commonly consumed in Northern Mexico. J Agric Food Chem 42:2204-2209

\section{Submit your manuscript to a SpringerOpen ${ }^{\circ}$ journal and benefit from:}

- Convenient online submission

- Rigorous peer review

- Immediate publication on acceptance

- Open access: articles freely available online

- High visibility within the field

- Retaining the copyright to your article 